\title{
ENVIRONMENTAL SCANNING ELECTRON MICROSCOPY (ESEM) OF Morinda citrifolia L. (Rubiaceae) COLLETERS
}

\author{
Sergimar Kennedy de Paiva PINHEIRO ${ }^{1}$, Francinalda Xavier de SOUSA ${ }^{1}$, Paulo Rafael Lima de \\ MEDEIROS $^{2}$, Thaiz Batista Azevedo Rangel MIGUEL ${ }^{2} \&$ Emilio de Castro MIGUEL $^{2 *}$
}

\begin{abstract}
1 Universidade Federal do Ceará, Departamento de Engenharia de Pesca, Central Analítica da Universidade Federal do Ceará/Programa de Pós-graduação em Biotecnologia de Recursos Naturais, Fortaleza, Ceará, Brazil.

2 Universidade Federal do Ceará, Departamento de Física/Central Analítica da Universidade Federal do Ceará, Fortaleza, Ceará, Brazil.

* Corresponding author: emilio.decastromiguel@gmail.com
\end{abstract}

http://dx.doi.org/10.18571/acbm.092

\begin{abstract}
This study describes the colleters of Morinda citrifolia L. (Rubiaceae) by using environmental scanning electron microscopy (ESEM) and energy dispersive x-ray spectroscopy (EDS). Two different developmental stages were characterized as well as the chemical composition of secretion. Colleters are secretory structures that produce mucilage protecting the meristems and leaf primordia against desiccation and/or pathogens. Although these secretory structures are common on Rubiaceae, the results reported here is to the best of our knowledge the first record of colleters on Morinda genus. Colleters are present at the stipule adaxial surface, distributed in lines. These secretory structures are standard type and have no base constriction, differently from all studied species until now. In order to better understand the colleters structure and secretion, two phases were distinguished: a secretory phase and a senescence one. On secretory phase standard type colleters were visualized between leaf primordia and stipule, emerge on secretion. They present smooth surface, however was also possible to observe the contours of secretory cells anticlinal walls. In senescent phase colleters morphology was alternated exhibiting rough surface and blunt to point tips. The surface was rough and on stipule sections was possible to observe idioblasts with raphides bundles. The secretion process of $M$. citrifolia colleters occurs with the disruption of cuticle and the chemical elements are mostly dominated by carbon and oxygen.
\end{abstract}

Key words: Secretory structure; colleters; Rubiaceae; stipule; secretory cells.

\section{RESUMO}

Este estudo descreve os coléteres de Morinda citrifolia L. (Rubiaceae), sob microscopia eletrônica de varredura ambiental. Duas fases de desenvolvimento diferentes foram caracterizados, bem como da composição química da secreção. Coléteres são estruturas secretoras que produzem proteger o meristemas e folha primórdios contra a dessecação e / ou patógenos mucilagem. Embora estas estruturas secretoras são comuns em Rubiaceae este foi o primeiro registro de coléteres em Morinda género. As amostras foram coletadas e analisadas em microscopia eletrônica de varredura ambiental (ESEM), incluindo espectroscopia de raios-x de energia dispersiva (EDS). Coléteres estão presentes na superfície adaxial stipule, distribuídos em linhas Estas estruturas secretoras são do tipo padrão e não tem nenhuma constrição base, diferente de todas as espécies estudadas até agora A fim de melhor compreender a estrutura coléteres e secreção, duas fases foramdistinguidos..: uma fase secretória e uma senescência. Em coléteres tipo padrão de fase secretora foram visualizados entre primórdios foliares e stipule, emergem sobre a secreção. Eles apresentam superfície lisa, no entanto, também foi possível observar os contornos de células secretoras paredes anticlinal. Em coléteres fase senescentes 
morfologia foi alternada exibindo superfície áspera e sem corte às pontas ponto. Em troços stipule foi possível apresenta idioblastos de ráfides feixes. $\mathrm{O}$ processo de secreção de M. Coléteres citrifolia ocorre com o rompimento da cutícula e os componentes químicos são na maior parte de carbono e oxigénio.

Palavras-chave: Estrutura secretora; Coléteres; Rubiaceae; Estipulas; Células secretoras.

\section{Introduction}

Rubiaceae is the fourth largest family of flowering plant comprising about 13,000 species, distributed in approximately 650 genera (ROBBRECHT, 2006). This family is quite diverse and distributed in various biomes. In Brazil, this family comprises about 118 genera and 1600 species represented by herbs, shrubs and trees, and less frequent liana (DELPRETE, 1998). They have simple opposite leaves, with interpeciolar stipule. The flowers are usually hermaphrodite or less frequently unisexual (SOUZA AND LORENZI, 2005). Among many genera we can found Morinda L.

The genus Morinda comprises circa 40 species, distributed mainly in the pantropical region (KESONBUAA AND CHANTARANOBHAI, 2013). The species occur in primary and secondary forests and scrubs in the lowlands as well as at higher altitudes.

Morinda citrifolia L., commonly known as "noni" is native to Southeast Asia (Indonesia) to Australia (DIXON et al., 1999; FLEMING, 2000). Specimens are small trees or large shrubs and grow in dry and wet areas, in acidic and alkaline soils, and even in infertile soil conditions. Morinda citrifolia L. has been known for its medicinal value since 2000 years ago. The juice of noni has become a popular nutraceutical in the past two decades, with claims made that the drink can treat, cure or prevent a variety of diseases (WANG et al., 2002, 2008; CHANBLANCO et al., 2006; DENG et al., 2007).

Studies suggested that Morinda citrifolia extracts has many effects as analgesic effect (YOUNOS et al., 1990), as well as effects against tumors (BROWN, 2002; SHARMA et al., 2015), inflammations (BASAR et al., 2010), and hypertension (GILANE et al, 2010), for example. In South-East Asia, the fruits are used to treat diabetes, as well as swollen spleen, liver diseases and cough (EE et al., 2009). Although Rubiaceae are characterized by the presence of stipular colleters, there are no records on literature referring to Morinda colleters.

Colleters are secretory structures characterized by elongated central axis formed by fundamental parenchyma, surrounded by an epidermal palisade layer (DA CUNHA \& VIEIRA 1993/97). This tissue is formed only of secretory cells (THOMAS 1991). The function of colleters is to protect the shoot apex and the lateral buds by a physical or chemical mechanism. This type of structure has been described by various names (THOMAS 1991; VAN HOV AND KAGOYRE 1974; DAVE AND PATEL 1975; CURTIS AND LERSTEN 1980), thus making it complicated to classify from the morphological point of view. Based on morphological data, Rubiaceae colleters are mainly designated as: standard reduced standard, dendroid, intermediate, brush-like, winged, filiform (THOMAS 1991; SIMÕES ET AL. 2006) and lachrymiform (MIGUEL ET AL. 2010).

The presence of crystals in colleters represents a taxonomically relevant characteristic (EVERT 2006). Different morphological types of colleters have been used successfully as morphological markers in taxonomic studies within various botanical families (RIO ET AL. 2005; SIMÕES ET AL. 2006).

Besides the colleter secretion is still poorly characterized, it is a consensus that these structures release mucilage or a mucilage-resin mixture (FAHN 1979). The exudate of Allamanda cathartica (Apocynaceae) colleters is a resin with big polymers and was 


\section{Biomédica Brasiliensia}

characterized by ABDEL-KADER et al., (1997). Sugars, but not amino acids, were found in the same secretion (THOMAS AND DAVE 1989). The presence of proteins in Simira colleter secretions was first described by Klein et al. (2004) and for B. nicholsonii (MIGUEL ET AL., 2006). A $\beta-1,3$-glucanase in S. glaziovii was characterized by Vieira et al. (2004). The composition of colleter secretions can play a role in protection against pathogen, by protecting the shoot apex.

Despite the morphological homogeneity of Rubiaceae colleters, variations can be useful on taxonomic and anatomic studies. Part of this form variation, especially on surface morphology, can be induced by sample preparation methods. Alternatively to classical sample preparation methods plant fragments can be observed by environmental scanning electron microscopy (ESEM) inducing minimal sample degradation. Thus, the aim of this work was to describe Morinda citrifolia colleters under ESEM as well as the chemical investigation of secretion, colleters and stipule by $\mathrm{x}$-ray microanalysis.

\section{Material and Methods}

\subsection{Plant collection}

Morinda citrifolia L. shoot apex containing stipules at different development stages were collected at Caucaia, Ceará-Brazil. Samples were immediately taken to Central Analítica da Universidade Federal do Ceará and investigated.

\subsection{Environmental scanning electron microscopy (ESEM)}

For Environmental scanning electron microscopy (ESEM) stipules fragments were removed and disposed on appropriated aluminum stubs. After the temperature stabilization the analysis were initiated.

Morphological analysis were carried at Quanta 450 FEG (FEI) with accelerating voltage of $10 \mathrm{kV}$, spot size 2.5 or 3.0 , final lens aperture of $30 \mu \mathrm{m}$ and work distance (WD) of 10 to $7 \mathrm{~mm}$ in low vacuum and wet mode, respectively. Images were obtained with a GSED detector.

\subsection{Energy dispersive spectroscopy (EDS)}

The samples were investigated by energy dispersive spectroscopy (EDS) on the same conditions of vacuum and humidity. The accelerating voltage was $20 \mathrm{kV}$, spot size 5.0 , final lens aperture of $30 \mu \mathrm{m}$ and work distance (WD) of $10 \mathrm{~mm}$. Images were obtained with an Oxford (model 150) EDS detector coupled to microscope. The images and graphics were obtained and processed with Aztec software (Oxford).

\section{Results}

\subsection{General characteristic}

Morinda citrifolia L. have persistent green stipules in vegetative (fig. 1A) apex and reproductive apex (fig. 1B). Careful observation of reproductive apex reveals stipules of approximately $4 \mathrm{~cm}$ on many nodes. Obovate to obcordate fused stipules remaining green for some nodes (fig. 1C). In the stipule abaxial base surface are found colleters. 


\section{ACTA}
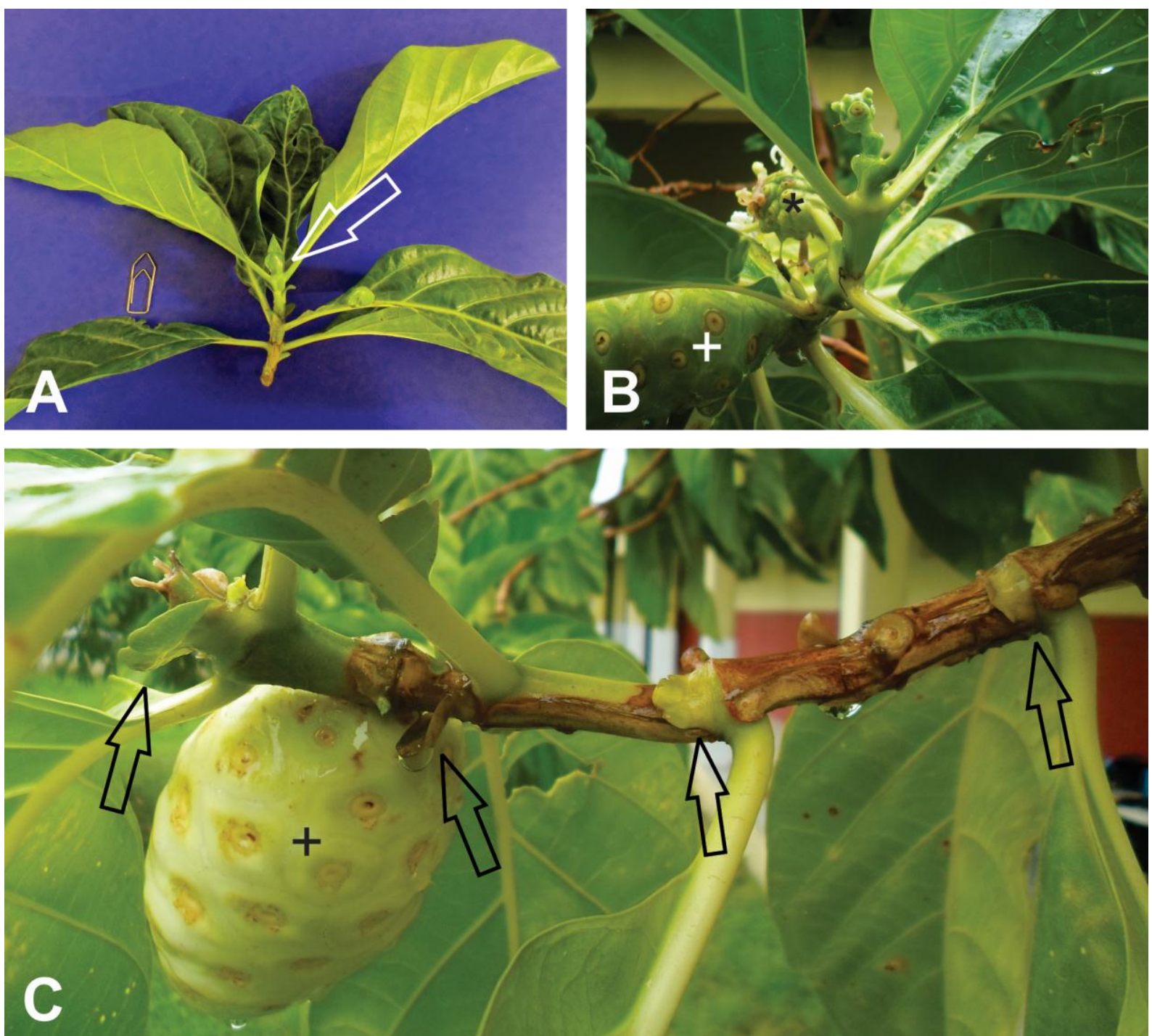

Figure 1: General view of Morinda citrifolia shoot apex. A - Vegetative shoot apex. Note stipules (open arrow) and leafs; B - Reproductive shoot apex. Observe fruit (+), young inflorescence (*) and stipule (open arrow); C Shoot apex exhibiting many nodes. Note persistent stipules (open arrow).

\subsection{Environmental scanning electron microscopy (ESEM) of secretory colleters}

In order to better understand the colleters structure and secretion, two phases were distinguished: a secretory phase and a senescence one. On shoot apex longitudinal section was possible to observe standard type colleters between leaf primordia and stipule, emerge on secretion (fig. 2A). The secretion was mucilagenous. A closer view reveal colleters with smooth surface. It was also possible to observe the contours of secretory cells anticlinal walls (Fig. 2B). Colleters tips are sharp (fig. 2C) and in some cases secretory colleters are so immerse on secretion that is not possible do define structures (fig. 2D). 


\section{Biomédica Brasiliensia}
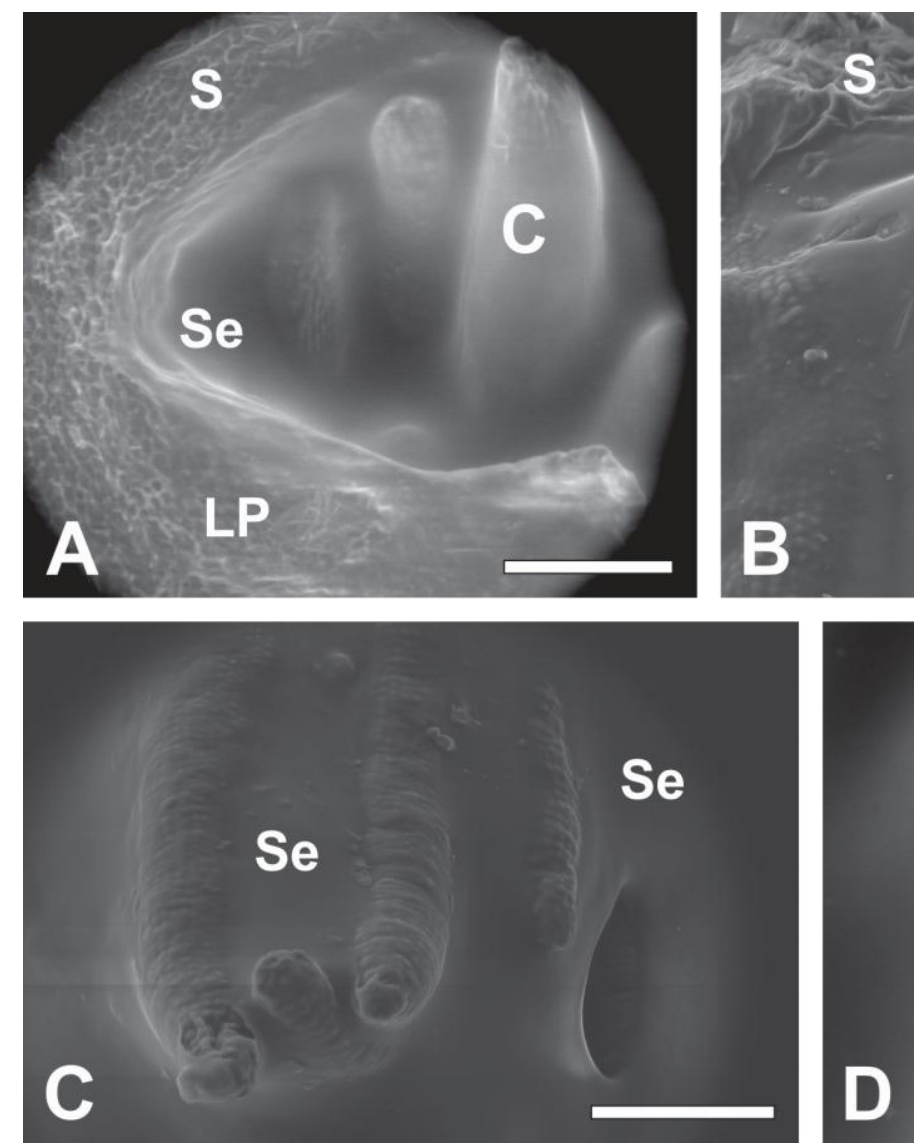

Se

Figure 2: Environmental scanning electron microscopy (ESEM) of stipular colleters of Morinda citrifolia on secretory phase. A - Longitudinal section of shoot apex. This section reveals stipule (S), leaf primordia (LP), and colleters (C) emerged from secretion; B - Stipule base colleters immerse on secretion (SE); C - Colleters immerse on secretion (SE); D - Colleter tip emerged from secretion. Note cuticle integrity. Bars: A, B, C - 200 $\mu$ m; D $50 \mu \mathrm{m}$.

\subsection{Environmental scanning electron microscopy (ESEM) of senescent colleters}

In senescent phase colleters, probably by dehydration of secretion, was possible to define colleters distributed in lines on stipule base (fig. 3A). On this phase, colleters morphology was alternated exhibiting rough surface (fig. 3A and 3B). Colleters are standard type with blunt to point tips (fig. 3B). A closer view on colleters tips review rough surface (fig. 3C). Secretion accumulated on stipule was dehydrated (fig. 3D). On stipule sections was possible to observe idioblasts with raphides bundles (fig. 3E). These raphides spread to stipule surface (fig. 3F). Raphides bundles was not observed on colleters. 

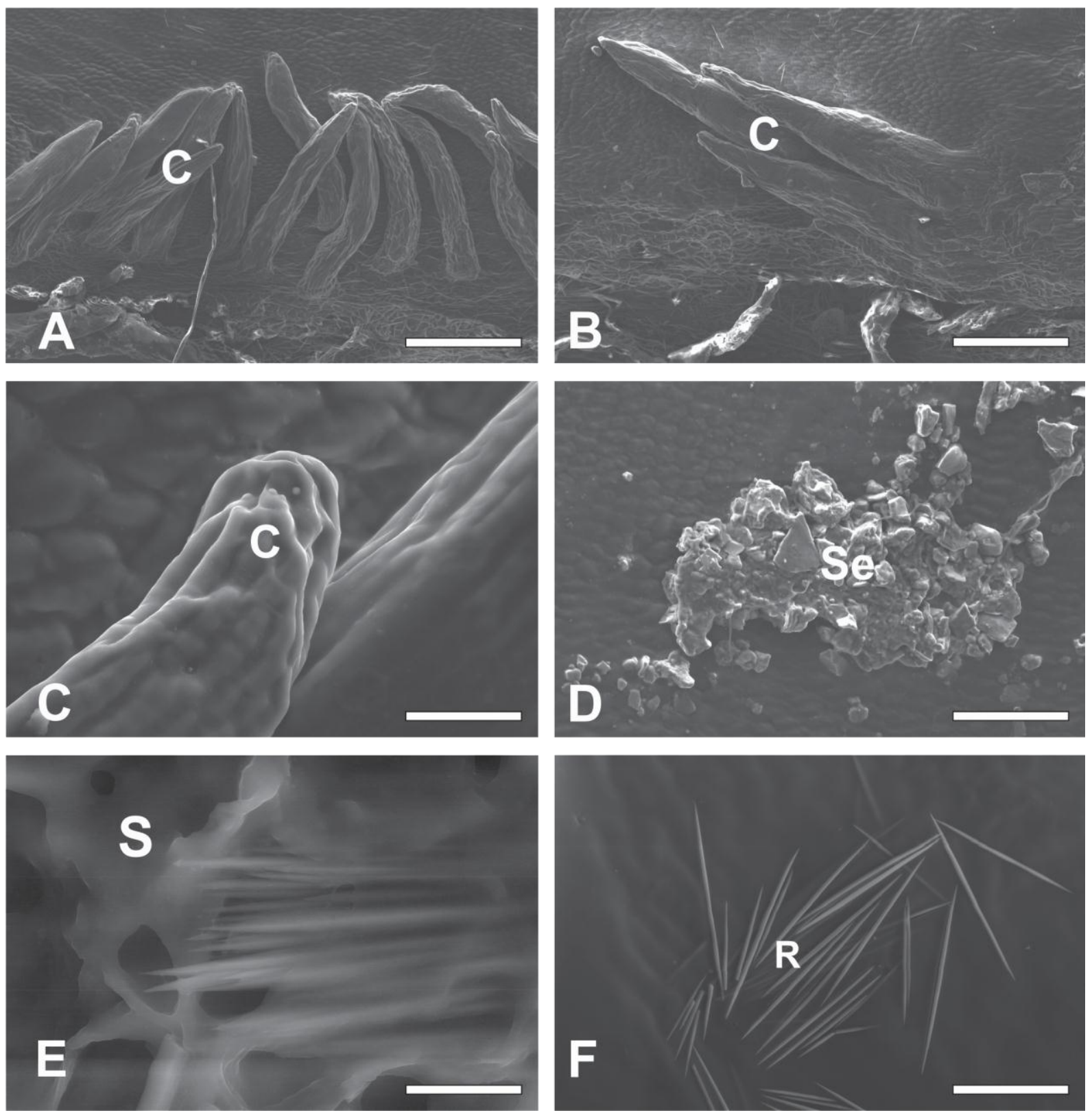

Figure 3: Environmental scanning electron microscopy (ESEM) of stipular colleters of Morinda citrifolia on senescent phase. A - Aligned colleters several in the stipules base; B - Three colleter aligned (C); D - Detail of stipular colleter (C); E - Dry Secretion (SE) in stipules (S); E - Stipule idioblast with raphides (R) on stipule; F -

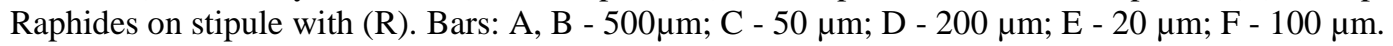

\subsection{Secretion mechanism}

Secretory colleters cells presents smooth surface without cuticle ornamentation (fig. 4A). Still on secretory phase was possible to observe cuticle distention, especially on colleters tip (fig. 4B). After distention, the cuticle starts the rupture (fig. 4C and 4D). After cuticle rupture the colleter increase surface roughness (fig. 4E), but is not possible to observe the rupture point (fig. $4 \mathrm{E}$ and $4 \mathrm{~F})$. 


\section{ACTA \\ Biomédica Brasiliensia}
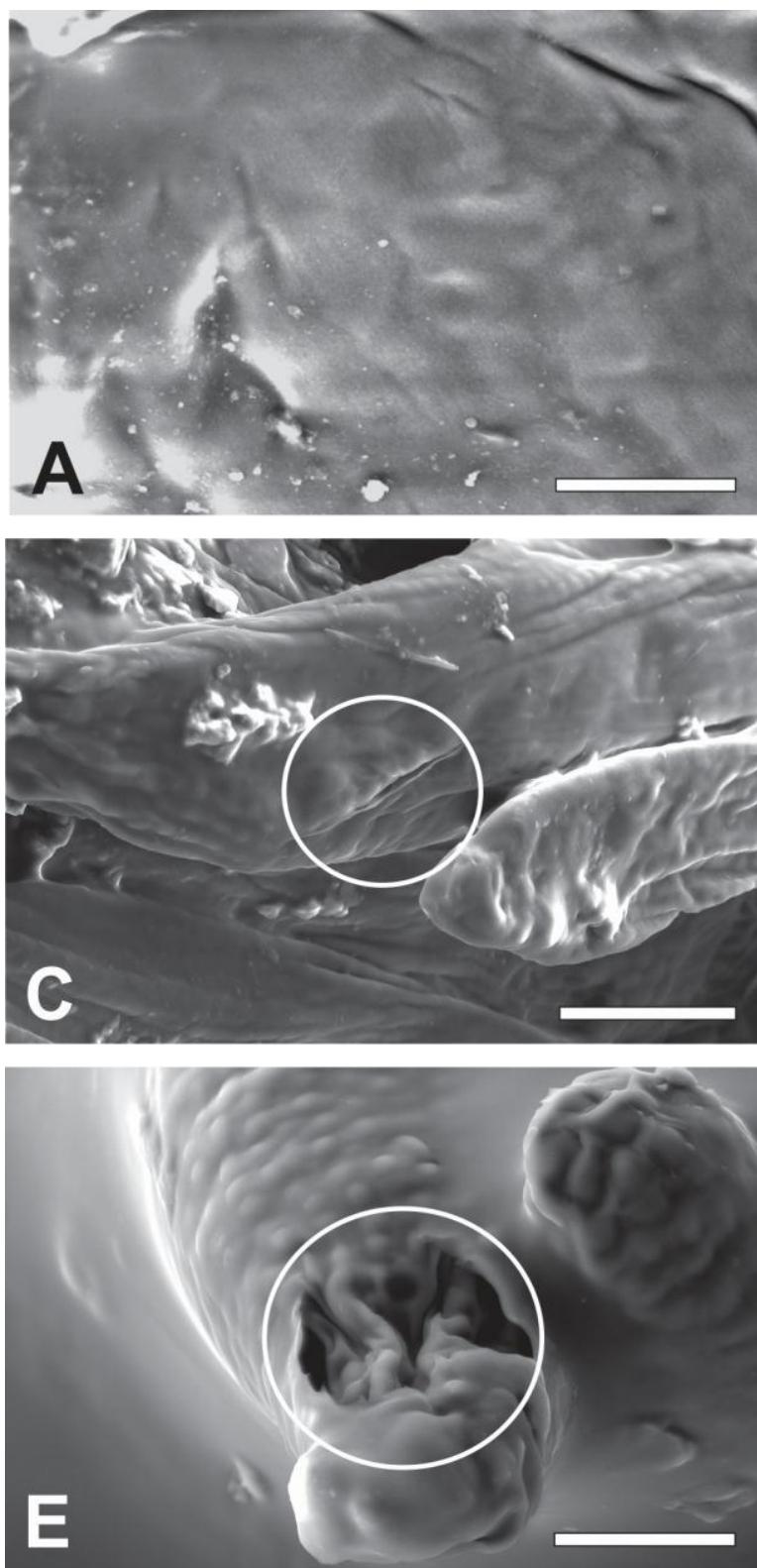

ISSN: 2236-0867
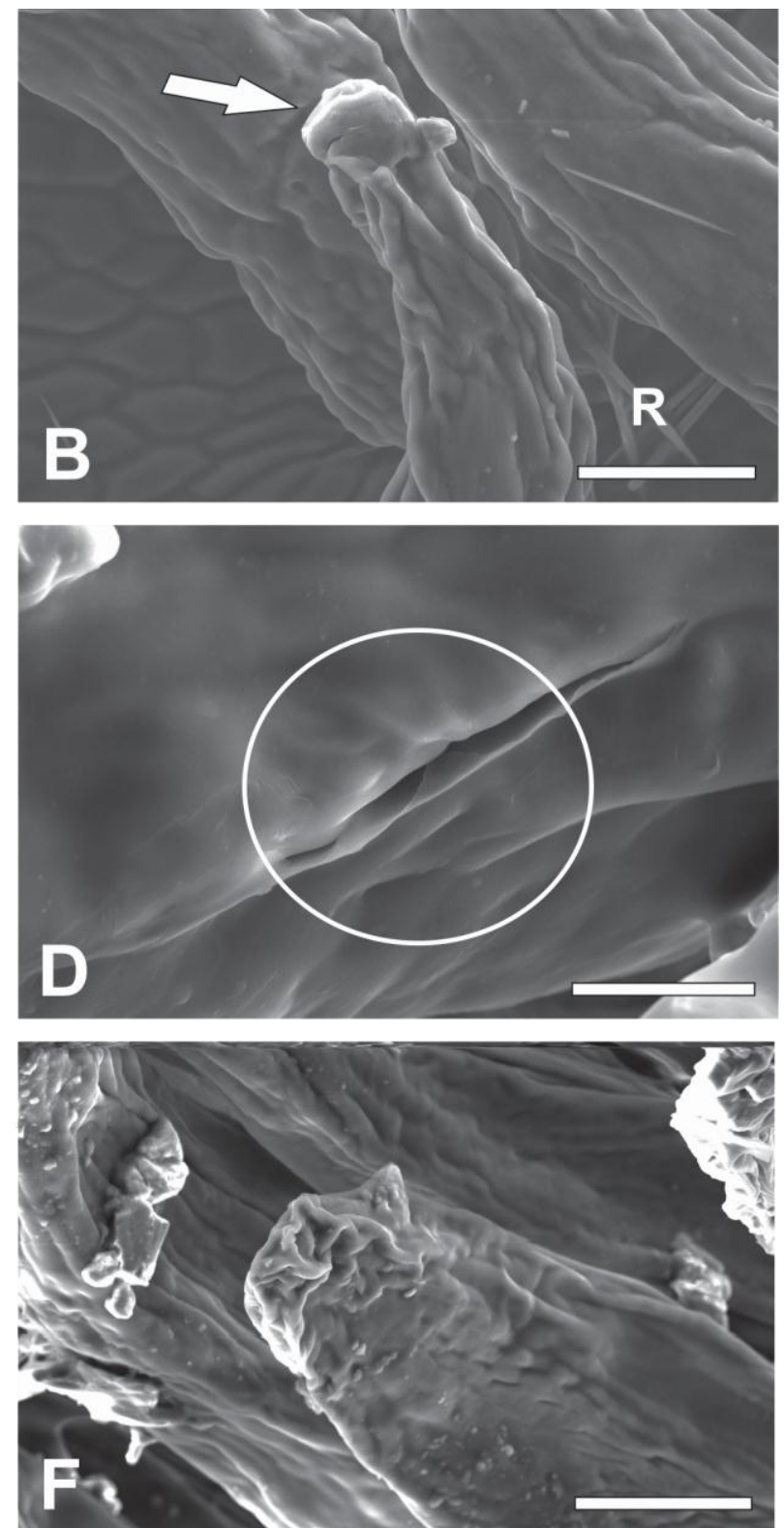

Figure 4: Environmental scanning electron microscopy (ESEM) of stipular colleters of Morinda citrifolia showing details of the breakdown of cuticle. A - Colleter with smooth cuticle, slightly ornate. B - colleter in secreation stage (Arrow). C - cuticle with Rupture the side (Circle). D - Detail with image showing the rupture of the cuticle (Circle). E - Colleter with Rupture of the cuticle (Circle) F - Colleter detail in senescence phase. Bars: A ,D - $20 \mu \mathrm{m}$; B,E $50 \mu \mathrm{m} ; \mathrm{C}, \mathrm{F}-100 \mu \mathrm{m}$.

\subsection{Energy dispersive X-ray spectroscopy (EDS)}

The qualitative analysis of the chemical elements that constitutes the colleters, secretion, and the secretion immerse on secretion (fig. 5A) revealed the predominance of carbon and oxygen (fig. 5B). Potassium and calcium were observed in small quantities (fig. 5B). 


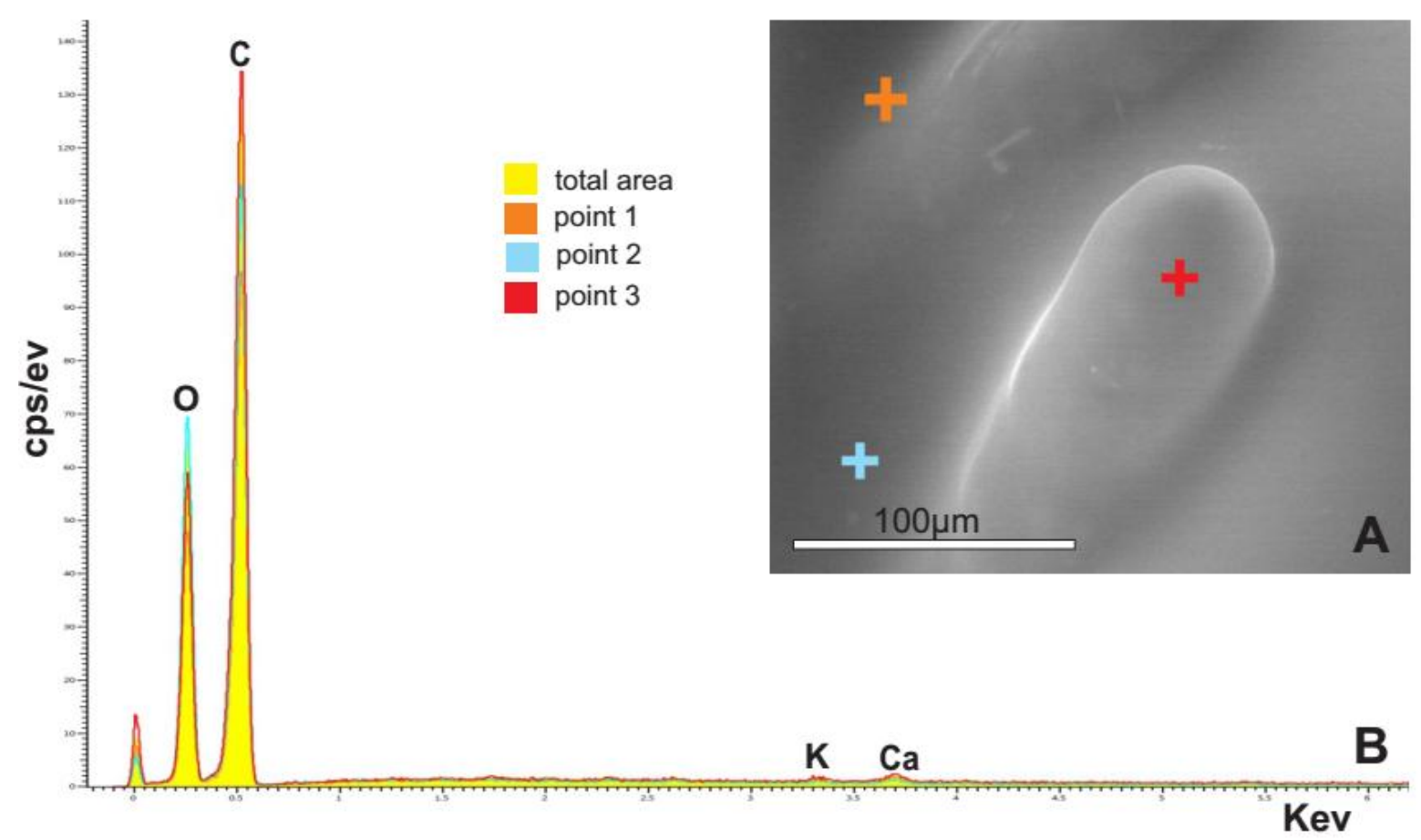

Figure 5: Environmental scanning electron microscopy (ESEM) and energy dispersive X-ray spectroscopy (EDS) spectra of colleters on stipule base. A - Scanning electron microscopy of colleters and secretion on stipule base; B $\mathrm{X}$-ray spectra showing main elements carbon and oxygen and minority potassium and calcium in all regions on different points and total area.

\section{Discussion}

Scanning electron microscopy revealed the presence of stipular colleters on Morinda citrifolia stipule adaxial surface. This was the first colleters record for this genera in spite of these structures have been described for many genera of this family.

Anatomically, colleters of Rubiaceae are constituted by a parenchymatic central axis with or without vascular bundles, surrounded by a layer of palisade-like epidermal cells (MIGUEL ET AL 2010; THOMAS, 1991). This structural pattern is regarded as a standard type of organization for all studied colleters. Variation of the standard type was found in the plants of the Rubiaceae (LERSTEN, 1974a, 1974b, MACHADO ET AL 2012), Turneraceae (GONZALEZ, 1998), Apocynaceae (SIMÕES et al., 2006; MARTINS, 2012), and Aquifoliaceae (GONZALEZ AND TAGARÓ, 2009). These variations can be useful on taxonomy (LOPES-MATOS ET AL 2015) and have also been investigated on functional aspects. Among functional aspects of colleters we can highlights secretion production and externalization.

The secretory process is continuous during the whole lifespan of the colleters. Thus it is incoherent to establish a borderline in time between what would be the secretory phase and the post-secretory phase (COELHO ET AL, 2013). However, for a better understand of secretion of colleters, many authors agree with this determination (MIGUEL ET AL, 2010, for example). Thus, the process of secretion of the colleters could be appreciated as process of programmed cell death that, once started, will only end with the death of the secretory cells in the senescent structure. The programmed cell death on colleters was previously demonstrated on Alseis pickelli (Rubiaceae) (TULLII ET AL, 2013).

Other point of discussion on colleters ultrastructure is the secretion passage through cell wall. Ultrastructural changes in the external walls (including the cuticle) of the secretory cells of colleters seem to be a prerequisite for the release of accumulated secretion when the cuticle is 


\section{Biomédica Brasiliensia}

not broken (THOMAS, 1991; KLEIN et al., 2004; MIGUEL ET AL., 2006, 2010; PAIVA, 2009; MACHADO et al., 2012; COELHO ET AL, 2013). On this study we clear identify cuticle rupture, clarifying one of many unclear aspects of secretion mechanisms on Morinda citrifolia colleters. For a better understand of secretion mechanism is quite necessary to investigate de chemical composition of secretion.

Colleters secretion is formed basically of mucilage (a mixture of polysaccharides, lipids, proteins and other substances (THOMAS 1991; MACHADO 2012). Although polysaccharides, proteins and lipids were histochemically detected in both colleter types, the relative abundance of lipids and polysaccharides and the variable appearance of the exudates on the apices can be related to different organ traits and climatic conditions of Cerrado during the sprouting and flowering phases (MACHADO ET AL, 2012). Some studies identified proteins on colleters secretion (MIGUEL ET AL, 2006). The predominance of carbon and oxygen on secretion, as revealed by x-ray microanalysis, agrees with previously studies describing the that secretion is primarilly composed by polysaccharides, lipids and proteins.

Further studies by using other techniques as scanning and transmission electron microscopy and optical microscopy are needed to fully understand the anatomy, ultrastructure and secretion on colleters of Morinda citrifolia.

\section{Conclusion}

The colleters of Morinda citrifolia was characterized as standard type and morphological similar to Rubiaceae colleters however, the lack of the base constriction is a new information on Morinda colleters. The possible secretion mechanism of cuticle rupture was previously described for other species but not for studied specie.

\section{Acknowledgment}

The authors would like to thank the Central Analítica-UFC/CT-INFRA/MCTISISNANO/Pró-Equipamentos CAPES and FUNCAP. The authors acknowledge Prof. Antonio G. Souza Filho for fruitful discussions.

\section{Bibliografia}

ABDEL-KADER, M. S.; WISSE, J.; EVANS, R.; WERFF, H.; KINGSTON, D. G. I.( Bioactive Iridoids and a New Lignan from Allamanda ca-thartica and Himatanthus fallax from the Suriname Rainforest. Journal of Natural Products, v. 60, p. 1294-1297, 1997.

BARBOSA, LOPES-MATTOS.; LUCAS, K.; OTUKI, P.; AKEMI, S.; AZEVEDO.; ALVES, A. Colleters in10 species belonging to three tribes of Rubiaceae: morphoanatomical diversity and potential as useful characters for taxonomy. Botany, v. 93, p. 425-434, 2015.

BASAR, S.; UHLENHUT, K.; HÖGGER, P.; SCHÖNE F.; WESTENDORF, J.; Analgesic and anti-inflammatory activity of Morinda citrifolia L. (Noni) fruit. Phytother Research v.24, p. 3842, 2010.

BROWN, A. C. Anticancer activity of Morinda citrifolia (Noni) fruit: a review. Phytotherapy Research. oct; 26(10):1427-40.Epub 2012 Feb 17, 2012.

CHAN-BLANCO,Y.; VAILLANT, F.; PEREZ, A. M.; M, REYNES. The noni fruit (Morinda citrifolia L.): A review of agricultural research, nutritional and therapeutic properties. Journal of 
Food Composition and Analysis, v.19, p. 645-654, 2006.

COELHO, V. P. M.; LEITE, J. P.V.; FIETTO, L. G.; VENTRELLA, M. C. Colleters in Bathysa cuspidata (Rubiaceae): Development, ultrastructure and chemical composition of the secretion. Flora, v. 208, p. 579-590, 2013.

CRISTIANE, F. T.; EMILIO, C. M.; NATHÁliA, B. L.; KÁTIA, V. S.; FERNANDES.; VALDIRENE, M. G.; MAURA DA CUNHA. Characterization of stipular colleters of Alseis pickelii. Botany, V. 91(6), P. 403-413, 2013.

CURTIS, J. D.; LERSTEN, N. R. Morphology, seasonal variation and function of resin glands on buds and leaves of Populus deltoides (Salicaceae). American Journal of Botany v.6, p. 835845,1974 .

CURTIS, J. D.; LERSTEN. N. R. Morphology and Anatomy of Resin Glands in Salix lucida (Salicaceae) American Journal of Botany, v. 67, p. 1289-1296,1980.

DA CUNHA.; M.; VIEIRA, R. C. Anatomia foliar de Psychotria velloziana Benth. (Rubiaceae). Rodriguésia, v. 49, p. 39-50,1993/97.

DAVE, Y.; PATEL, N. D. A developmental study of extrafloral nectaries in slipper spurge (Pedialanthus tithymaloides, Euphorbiaceae). American Journal of Botany, v. 62, p. 808-812, 1975.

DELPRETE, P. G. Sinopse dos gêneros de Rubiaceae do Brasil. Livro de resumos do $4^{\circ}$ Congresso Nacional de Botânica, p. 85-86, 1998.

DENG, S.; PALU, K.; WEST, B. J.; SU, C.; ZHOU, B. N.; JENSEN, J. C. Lipoxygenase Inhibitory Constituents of the Fruits of Noni (Morinda citrifolia) Collected in Tahiti. Journal of Natural Products, v.60, p. 859-862, 2007.

DIXON, A. R.; MCMILLEN, H.; ETKINETIN, N. L. Ferment this: the transformation of Noni, a traditional Polynesian medicine (Morinda citrifolia, Rubiaceae). Economic Botany v.53, p. 51-68, 1999.

EE. G. C. L.; WEN, Y. P.; SUKARI, M. A.; G, O. R.; LEE, H. L. A new anthraquinone from Morinda citrifolia roots. Natural Products Report, v. 23, p. 1322-1329, 2009.

EVERT, R. F. Esau's plant anatomy, meristems, cells, and tissues of the plant body: their structure, function, and development. 3rd edn. Wiley,New Jersey, 2006.

FAHN, A. Secretory tissues in plants. Academic, London, 1979.

FLEMING, T. PDR of Herbal Medicines, second ed. Montvale, New Jersey. Medical Economics Company, 2000.

GILANE, A. H.; MANDUKHAIL, S. U. R.; IQBAL, J.; YASINZAI, M.; AZIZ, N.; KHAN, A.; REHMAN, N. U. Antispasmodic and vasodilator activities of Morinda citrifolia root extract are mediated through blockade of voltage dependent calcium channels. BMC complementary and alternative medicine, v.10, p.1-10, 2010. 
GONZÁLEZ, A. M. Colleters in Turnera and Piriqueta (Turneraceae). Botanical Journal of the Linnean Society, v.128, p. 215-228, 1998.

GONZALEZ. A. M.; TARRAGO, J. R. Anatomical structure and secretion compounds of colleters in nine Ilex species (Aquifoliaceae) from southern South America. Botanical Journal of the Linnean Society, v.160, p. 197-210, 2009.

KESONBUAA, W.; CHANTARANOTHAI, P. The genus Morinda (Rubiaceae) in Thailand. Science Asia. v. 39, p. 331-339, 2013.

KLEIN, D. E.; GOMES, V. M.; SILVA-NETO, S. J.; DA CUNHA, M. The structure of colleters in several species of Simira (Rubiaceae). Annals of Botany, v. 94, p. 733- 740, 2004.

LERSTEN, N. R. Morphology and distribution of colleters and crystals in relation to the taxonomy and bacterial leaf nodules in Psychotria (Rubiaceae). American Journal of Botany, v. 61, p. $973-981,1974 \mathrm{a}$

LERSTEN, N. R. Colleter morphology in Pavetta, Neorosea and Tricalysia (Rubiaceae) and its relationship to the bacterial leaf nodule symbiosis. Botanical Journal of Linnaean Society, v. 69, p. 125-136, 1974b.

MACHADO, S. R.; BARREIRO, D. P.; ROCHAC, J. F.; RODRIGUES, T. M. Dendroid colleters on vegetative and reproductive apices in Alibertia sessilis (Rubiaceae) differ in ultrastructure and secretion. Flora, v. 207, p. 868-877, 2012.

MARTINS, F. M. Leaf and calycine colleters in Odontadenia lutea (Apocynaceae Apocynoideae - Odontadenieae): their structure and histochemistry. Brazilian Journal of Botany, V. 35, p. 59-69, 2012.

MIGUEL, E. C.; GOMES V. M.; OLIVEIRA, M. A.; DA CUNHA, M. Colleters in Bathysa nicholsonii K. Schum. (Rubiaceae): ultrastructure, secretion protein composition, and antifungal activity. Plant Biology, v. 8, p.715-722, 2006.

MIGUEL, E. C.; KLEIN, D. E.; OLIVEIRA, M. A.; CUNHA, M. Ultrastructure of secretory and senescence phase in colleters of Bathysa gymnocarpa and B. stipulate (Rubiaceae). Revista Brasileira de Botânica, v. 33, p. 425-436, 2010.

PAIVA, E. A. S. Occurrence, structure and functional aspects of the colleters of Copaifera langsdorffii Desf. (Fabaceae, Caesalpinioideae).Comptes Rendus Biologies, v. 332, p. 10781084, 2009.

RIO, M. C. S.; KINOSHITA, L. S. Prestonia (Apocynaceae) no Sul e Sudeste do Brasil. Hoehnea, v. 32, p. 233-258, 2005.

RIO, M. C. S.; KINOSHITA, L. S.;CASTRO M. M. Anatomia foliar como subsídio para a taxonomia de espécies de Forsteronia G.Mey. (Apocynaceae) dos cerrados paulistas. Revista Brasileira de Botânica, v. 28, p. 713-726. 2005.

ROBBRECHT, E. The major evolutionary lineages of the coffee family (Rubiaceae, angiosperms). Systematics and Geography of Plants Guide for authors, v. 76, p. 85-146, 2006. 
SHARMA, K. PACHAURI, S. D, KHANDELWAL, K.; AHMAD, H.; ARY, A.; BIALA, P.; AGRAWAL, S.; PANDEY, R. R.; SRIVASTAVA, A.; SRIVASTAV, A.; SAXENA, J. K.; DWIVEDI A. K.; Anticancer Effects of Extracts from the Fruit of Morinda Citrifolia (Noni) in Breast Cancer Cell Lines., DRUG RES (STUTTG). [Epub ahead of print], 2015.

SIMÕES, A. O.; CASTRO, M. M.; KINOSHITA, L. S. Calycine colleters of seven species of Apocynaceae(Apocynoideae) from Brazil. Botanical Journal of the Linnean Society, v. 152, p. 387-398, 2006.

SIMÕES, A. O.; CASTRO, M. M.; KINOSHITA, L. S. Calycine colleters of seven species of Apocynaceae(Apocynoideae) from Brazil. Botanical Journal of the Linnean Society, v. 152, p. 387-398, 2006.

SOUZA, V. C.; LORENZI, H. Botânica sistemática: Guia ilustrado para identificação das famílias de Angiospermas da flora brasileira, baseado em APG II. Plantarum, Nova Odessa, 2005.

THOMAS, V. Structural, functional and phylogenetic aspects of the colleter. Annals of Botany, v.68, p. 287-305, 1991.

THOMAS, V.; DAVE, Y. Histochemistry and senescence ofcolleters of Allamanda cathartica (Apocynaceae). Annals of Botany, v. 64, p. 201-203, 1989.

VAN HOVE, C.; KAGOYRE, K. A comparative study of stipular glands in nodulating and nonnodulating species of Rubiaceae. Annals of Botany, v. 38, p. 989-991,1974.

VIEIRA, F. A. ; CUNHA, M.; KLEIN, D. E ; CARVALHO, OLIVEIRA, A ; GOMES, V. M. Purification and characterization of b-1,3-glucanase from the secretion of Simira glaziovii colleters (Rubiaceae). Brazilian Archives of Biology and Technology, v. 49, p. 881-888, 2006.

VIEIRA, F. A.; CUNHA, M. A.; KLEIN, D. E.; CARVAlHO, A. O.; GOMES, V. M. Purification and characterization of b-1,3-glucanase from the secretion of Simira glaziovii colleters (Rubiaceae). Brazilian Archives of Biology and Technology, v. 49, p. 881-888, 2006.

WANG, M. Y.; WEST B. J.; JENSEN, C. J.; NOWICKI, D. et al. Morinda citrifolia (Noni): a literature review and recent advances in Noni research. Acta Pharmacologica Sinica, v. 23, p.1127-1141, 2002.

YOUNOS. C.; ROLLAND, A.; FLEURENTIN, J.; LANHERS, M. C.; MISSLIN, R.; MORTIER, F. Analgesic and behavioural effects of Morinda citrifolia. Planta Medica, v. 56, p. 430-4, 1990. 